Chicago-Kent College of Law

Scholarly Commons @ IIT Chicago-Kent College of Law

All Faculty Scholarship

Faculty Scholarship

January 2003

\title{
The European Commission's GE/Honeywell Decision: U.S. Responses and Their Implications
}

David J. Gerber

IIT Chicago-Kent College of Law, dgerber@kentlaw.iit.edu

Follow this and additional works at: https://scholarship.kentlaw.iit.edu/fac_schol

Part of the Antitrust and Trade Regulation Commons, Comparative and Foreign Law Commons, and the European Law Commons

\section{Recommended Citation}

David J. Gerber, The European Commission's GE/Honeywell Decision: U.S. Responses and Their Implications, $87 \mathrm{~J}$. of Competition L. 87 (2003).

Available at: https://scholarship.kentlaw.iit.edu/fac_schol/250

This Article is brought to you for free and open access by the Faculty Scholarship at Scholarly Commons @ IIT Chicago-Kent College of Law. It has been accepted for inclusion in All Faculty Scholarship by an authorized administrator of Scholarly Commons @ IIT Chicago-Kent College of Law. For more information, please contact jwenger@kentlaw.iit.edu, ebarney@kentlaw.iit.edu. 
David J. Gerber*)

\section{The European Commission's GE/Honeywell Decision: US responses and their implications}

In the summer of 2001, the European Commission probibited the proposed merger between GE and Honeywell. The US responses to that decision reveal much about differences between the merger laws of the US and the EU. They also have potentially important implications for the development of US-European cooperation in the area of competition law.

One way of gaining insight into differences between legal systems and assessing their significance is to examine what they - i.e., their representatives - say about each other. The European Commission's prohibition of the proposed merger between GE and Honeywell in the summer of 2001 led to US responses that reveal much about differences between the US and EU merger laws. They also have potentially important implications for the development of US-European cooperation in the area of competition law. Although there has been general discussion of these responses, there have been few serious attempts to analyze them and to explore their implications for legal development. In this brief comment, I suggest some lines of analysis that may provide insights into the US responses and their potential importance.

This type of analysis is uncommon. Where government officials and others respond to foreign legal decisions, they are usually assumed to be engaging in political gamesmanship that has little or no relevance for legal analysis. Accordingly, there is little perceived incentive to look carefully at their responses. In the context of traditional (i.e., pre-globalization) relationships among legal systems, this assumption is generally justified.

In the globalization context, however, additional questions deserve attention. Where two or more legal systems share a common objective to cooperate in dealing with problems common to them and others, such responses take on a new role. They now become signaling mechanisms within cooperative relationships, and as such they need to be seen as part of a legal dialogue that is the basis for interactions between decision makers. We need to look more carefully, therefore, at the perspectives that produce these responses and the factors that shape those perspectives.

I here look at several US responses to the GE/Honeywell decisions from this angle. I identify some of the structures of thought reflected in them, note some of the factors that have shaped those structures, and touch on some of the implications of those responses. This review suggests that behind these US

*) Distinguished Professor of Law, Chicago-Kent College of Law, Chicago, Illinois 
responses are structural elements that over time are likely to impede international competition law cooperation. ${ }^{1)}$

The scope of these remarks is limited. First, they are not intended to be comprehensive. I look at responses that have been common and influential, but not all US responses contain all the elements described here, and some are quite different. Second, my objective here is not to judge whether the responses are "right" or "wrong", but to gain insight into them and to recognize their implications.

\section{U.S. RESPONSE PATTERNS}

Four themes have been particularly prominent in U.S. responses to the decision. One is outrage that the EU would dare to prohibit a merger between two US companies that had been approved by US authorities. According to one account, "... Americans are asking how a foreign authority could scuttle a deal that involved only U.S. companies and the Justice Department and about a dozen other competition authorities had approved with modest concessions".2) The underlying assumption is that the EU simply had no right, legal or moral, to do what it did.

A second theme is that the decision was not based on the application of law, but was instead motivated by political considerations - specifically, the desire to protect domestic European industries. The economist Gary Becker claimed that "Europe appears to be guilty of caving in to powerful interests". ${ }^{3)}$ This claim is seldom, if ever, supported by evidence. It represents an interpretation: benefit to European competitors of US firms is assumed, and this is further assumed to be the basis for the decision. ${ }^{4)}$

A weaker form of this claim is that the system is "regulatory" in nature, and thus impliedly less "legal", less neutral and less objective than the US system. The further implication is that this allows the Commission to pursue its own political objectives. According to one commentator, for example, "These differences [in outcome] - and the strengths and weaknesses of the two systems - flow from

1) In the short-run, the responses can have the beneficial effect of focusing attention on the problems of cooperation and on the differences between systems. My concern here, however, is whether they contribute to a better understanding of those differences and to resolution of the problems identified.

2) William Kolasky or Leon B. Greenfield, The Lost GE/Honeywell Deal Reveals a Transatlantic Clash of Essentials, Legal Times 28 (July 30, 2001).

3) Gary Becker, What U.S. Courts Could Teach Europe's Trustbusters, Business Week, Aug. 6, 2001, at 20. In a letter to the European authorities, Senator Ernest Hollings, Chairman of the Senate Commerce Committee, stated the Commission had applied "an apparent double standard that favored European companies and disadvantaged their U.S. competitors". U.S. Steps in over EU Opposition to G.E. Deal, Financial Times, June 16/17, 2001, at 1.

4) In fact, the most strenuous opponents of the merger were probably US firms rather than European firms. 
the fact that while the Antitrust Division [of the Justice Department] operates in a law enforcement context, the Merger Task Force [of the EU Commission] operates in a regulatory system".5)

A third claim, particularly common among antitrust specialists, is that the EU Commission was simply wrong in its analysis. ${ }^{6}$ Here the assumption is that the US and EU decisionmakers were applying the same standard and seeking the same objectives, but the EU misunderstood the economics of the case and thus got the analysis wrong. There is seldom explicit reference in such claims to the standard that is being applied in arriving at this conclusion, and they seldom reflect careful comparison of the standards and objectives used in US and EU law.

Finally, and related, it has often been claimed that the objectives of EU competition law are wrong in the sense that they are inappropriate for competition law. A frequent claim is, for example, that "EU law protects competitors, while US law protects competition". Charles James, Assistant Attorney General for Antitrust, stated in a press release that "Clear and longstanding U.S. antitrust policy holds that the antitrust laws protect competition, not competitors. Today's EU decision reflects a significant point of divergence".7) This claim perceives the differences in outcomes as the result not of faulty analysis based on similar standards, but of a fundamental discrepancy in objectives.

\section{STRUCTURAL ELEMENTS IN U.S. RESPONSES}

This set of responses reflects several basic structures in the US perspective. By "structures" I mean relatively stable elements such as assumptions and beliefs that are regularly used (consciously or unconsciously) to interpret information and shape responses to European (and other foreign) competition law decisions. These "heuristics" shape the way information is perceived, ordered and given meaning, and thus an analysis that identifies them provides insights into the responses they shape.

\section{How (Competition) Law Works}

One set of assumptions relates to the way competition law functions. It casts competition law decision-making as political in nature. For example, the claim that the Commission was acting politically is not supported by evidence, and

5) Donna E. Patterson \& Carl Shapiro, Transatlantic Divergence in GE/Honeywell: Causes and Lessons, 16 Antitrust 18, 22 (Fall, 2001).

6) See, e.g., William J. Kolasky, Conglomerate Mergers and Range Effects: It's A Long Way from Chicago to Brussels, address before the George Mason University Symposium, Washington D.C., Nov. 9, 2001 (www.usdoj.jov/atr/public/speeches/9536.htm).

7) Charles A. James, Statement on the EU's Decision Regarding the GE/Honeywell Acquisition (July 3, 2001; available at www.usdoj.gov/atr/public/press_releases/2001/8510.htm). 
thus the conclusion that it is acting politically appears to be produced by the interpretive assumptions of those who make the claim rather than the evidence available. In other words, the conclusion is produced by the interpretive lenses being employed rather than by the factual data being presented.

This is associated with the further assumption that legal decisions are not only political, but specifically intended to promote the single-state interests of the decision maker. The distinction here is between single-state and shared interests. Governmental decision makers generally pursue the interests of the state in which they operate; the issue is how they define those interests. The assumption at work in these responses is that the Commission acts to produce direct and tangible benefits to its domestic political constituents and that these interests take the form of advantages over the US competitors of European businesses. A shared interests perspective would also consider benefits to the state that may provide benefits to other states (e.g., more effective competition law development or more effective international cooperation).

\section{The Relationship between Law and Economics}

Assumptions and beliefs about the relationship between law and economics form a further structural element in many US responses. They often assume that economics is the controlling language in competition law matters, that it represents an independent and universal standard against which competition laws are to be measured and assessed. Typically, this is accompanied by a further assumption that the correct standard is a specific form of economic analysis known generally as "Chicago school" analysis, which focuses on short-term price increases as the measure of economic efficiency. ${ }^{8)}$ This conception of economic analysis is used as the standard to which all competition law systems should adhere.

This assumption is of crucial importance for two reasons. First, it disregards differences in the laws of the two systems and tends to preclude serious discussion of those differences. Where the discussion is reduced to the language of economics, other factors that a decision maker may be required or expected to take into consideration - such as, e.g., the articulated legal standards provided by the laws being applied - are excluded. The result may be to misunderstand and distort the decisional processes involved and the motivations of the decision makers. In the GE/Honeywell context, its implication is that $\mathrm{EU}$ decision makers were at liberty to act on what they considered to be the best economic analysis, regardless of existing statutes and policies. This is simply inaccurate. Second, it tends to disregard differences in economic analysis. Short-term price effects may currently be the sole concern in US antitrust, but that does not mean that they are the only concerns of economics.

8) For a classic discussion of this approach, see Robert H. Bork, The Antitrust Paradox: A Policy at War with Itself (1978). 


\section{Relations among Decision Makers}

A third set of assumptions involves the relationships among actors in the competition law arena. US responses assume certain characteristics of those relationships, and this leads to further assumptions about the probable effectiveness of particular response strategies.

The logic of power suffuses US responses. They frequently assume that US responses must not only be heard, but also heeded and followed. The tone is often that the US commentator has a right to expect that the Commission will make changes in accordance with her comments and that failure to do so (i.e., to follow the US example) will produce harmful consequences for the Commission. The fact of US power both encourages this type of response and implicitly turns such responses into threats. In this image of the relationships among competition law decision makers, there is no incentive to accord respect to the decisions of other decision makers. In a power-based relationship, the only respect due to the other party or parties is a function of their power. This tends to foster a lack of concern for the objectives and constraints on the Commission's decision making prerogatives.

In these responses, the relationships among competition law actors are seldom portrayed as legally imbedded. They are often treated as if they were not subject to legal principles at all. This treatment follows from the power-based perspective just noted, which tends to disregard the norms of international law. Yet few experts, if any, would challenge the right of the EU under public international law to apply its own law to conduct that has a substantial effect within its territory. This conclusion is based on the effects principle of international law, which is widely accepted as a general principle, although there continues to be controversy about its range and about how it should be applied in particular cases.

From a power-based perspective, there is also little incentive to engage in serious comparative analysis - to learn about the traditions, objectives and dynamics of another system. From this perspective, such knowledge appears to be, at best, useless; at worst, it may interfere with power-based response strategies. This logic may help to explain why US responses frequently lack rigorous analysis of the differences between the US and EU competition law systems and the reasons for them.

\section{SHAPING U.S. PERSPECTIVES}

These themes and perspectives are grounded in US experience, and we can indicate some of the elements of that experience that helped to shape them. The relevant experience is both general and antitrust-related, and it has both external and domestic components. 


\section{External Experience}

On one level, the external influence is obvious. The experience of US political leaders, lawyers and academics since the Second World War has been one of leadership (some might say "dominance") in its relationships with Europe. The political and economic power of the US has been accompanied by a general assumption in the US (and to some extent in Europe) that Europeans have an obligation to avoid serious interference with US goals. This power relationship easily leads to the further assumptions (1) that the US is "entitled" to tell the EU Commission what it should do and (2) that the EU Commission is "obligated" to heed the US demands. The tone and content of many US responses reflects this assumption.

Perhaps less obvious is the experience of US antitrust lawyers and scholars in their relations with their analogues from foreign countries (mainly Europe). US antitrust law is often seen as the progenitor (usually, "father") of antitrust law. Until after the Second World War, it was the only significant competition law, and it has long been the center of the antitrust universe. Others, including the Europeans, have been expected to look to and learn from US antitrust law, and the Europeans have frequently done so. Moreover, many still assume that European competition law is merely an import from the U.S.9)

Among members of the US antitrust community, this has often generated an assumption that US antitrust law is simply better - more sophisticated and better developed - than other competition law systems. In any event, they have seldom experienced situations in which they have been expected to learn from other competition law systems. As a result, the idea that the US can learn from others remains little developed, and this further contributes to an implicit sense of the superiority of the US system.

It also inhibits serious comparative analysis of EU competition law in the US. There is, of course, much writing and knowledge about particular cases and regulatory texts, but in-depth analysis of the goals, traditions, institutions and processes of European competition law remains uncommon in US legal discussions and scholarship.

\section{Internal experience}

The domestic experience of US antitrust lawyers and officials also helps to explain some of the assumptions that we have here encountered. Careful analysis of that experience can provide valuable insights into US responses, particularly because US experience of antitrust law is in many ways unique. Here are a few examples.

9) I have demonstrated that this assumption is inaccurate, but it persists nonetheless. For discussion of the evolution of competition law in Europe and the role of U.S. antitrust law in that evolution, see David J. Gerber, Law and Competition in Twentieth Century Europe (1998, pbk. 2001). 


\section{a) The Political Character of Antitrust}

The assumption that antitrust officials are heavily influenced by political considerations is encouraged by US antitrust history. US antitrust law, and particularly US antitrust enforcement, has undergone fundamental and often rapid changes at several points in its history, and these changes have often been based on political factors. In some ways the most fundamental of these changes is very recent. I refer to the victory of law-and-economics methodology that began in the 1970 s and radically changed much in US antitrust law. These changes are often assumed to have been to a large extent driven or at least supported by political factors, most notably the policies of Ronald Reagan's presidency. This experience predisposes those in the US antitrust community to assume that such political factors play similar roles in other systems as well.

\section{b) Distrust of Administrative Decisionmaking}

This is related to attitudes toward administrative decision making that are common in society, but particularly prevalent within the competition law community. In the US, administrative officials are often assumed to be vulnerable to political pressure, and this assumption is readily applied in the area of antitrust because of the magnitude of the economic and political interests that are often involved in antitrust decisions. This set of beliefs about administrative decisionmaking, particularly in the competition law arena, is readily applied to all systems. Given that administrators play a more central role in the application of EU competition law than they do in the US, the step to assuming political vulnerability in that system is a short one.

In the US system, the political vulnerability of administrators is thought to be offset by the central role of the federal courts in the system. For example, the Department of Justice generally must file suit in court in order to take enforcement action under the antitrust laws. This is understood as a mechanism for constraining political influence within the system. In the EU context, the Commission has extensive decisional and enforcement powers that are used with little or no court involvement. Its decisions may be reviewed by one of the two Community courts, but reviews often take several years, and relatively few have led to reversal of Commission decisions. This encourages suspicions about the Commission's objectivity as well as its motives.

\section{c) The Victory of Law and Economics}

The most prominent element of US antitrust experience over the last 25 years has been the victory of law and economics. Not surprisingly, this victory plays key roles in the shaping of US antitrust views. In particular, it shapes the way members of the US antitrust community view both the phenomenon of competition law and those who hold other views of competition law. 
Beginning in the late 1970s, scholars identified with the "law-and-economics"(L\&E) movement have argued that the goals of antitrust should be defined solely by reference to economic theory, in particular, Chicago school economics. This concept of antitrust law quickly won acceptance throughout the system during the $1980 \mathrm{~s}$, thus fundamentally reorienting competition law and competition law scholarship.

This recent and impressive "victory" has generated belief in the rectitude of the ideas, and it helps to explain why they have come to form a kind of orthodoxy in the U.S. The speed and ease of the victory are often seen as proof of their power: if they can be so successful in such a short period of time, they must be powerful. From here the step to assuming that they are also "right" in a universal sense is easy and often taken.

The experience of this victory has also created a kind of post-victory mode of thought in which there is often little willingness to consider perspectives other than those of the victors. The battle has been won. For many, the losing US antitrust ideas have been shown to be wrong, and they deserve little respect. Some of these ideas are seen as similar to ideas advanced by the European Commission, leading some members of the US antitrust community to discredit them by association.

The political element in this experience also ties the antitrust debate to issues of political ideology. From the perspective of economics, government actions that affect business decisions are viewed as "regulation" which "interferes" with the economy; they are, therefore, presumed to be harmful. This creates an agenda that has much in common with a political ideology that disfavors government action on often quite different grounds.

\section{CONCLUSIONS}

These brief comments on U.S. responses to the GE/Honeywell decision indicate the potential value of more careful analysis of such responses and of their potential impact on the development of competition law. In a context of international cooperation, responses take on functions that did not exist or had been marginal under previous circumstances. In the globalization context, they become part of the relationship between legal systems, and failure to view and understand them as such misses an important dimension of that relationship.

Closer study of US responses to a decision as important as the GE/Honeywell decision can thus constitute an important part of legal analysis. Such an analysis can uncover structural (and hence durable) elements in US perspectives that may impede long-term interaction and cooperation in dealing with the problems of a globalized economy. It can also identify important differences among systems that may not be readily noticed through other forms of analysis. 
These comments should not be read to suggest that US criticism of the Commission is inappropriate; on the contrary, such criticism can be of great potential value. The point here is that the value of criticism is increased to the extent that it reflects and takes into account the circumstances that surround it. Here that requires taking into account the new kind of transnational dialogue in which decisions are imbedded. At a minimum, this means that criticism should be based on adequate knowledge of the other legal system involved and on respect for the goals and problems its decision makers face.

\section{Abstract}

U.S. responses to the European Commission's prohibition of the GE-Honeywell merger reveal important differences in the assumptions underlying the operation of the US and EU merger systems. Most prominent are differing assumptions about the way competition law decisions are made and about the relationship between law and economics. They also reveal differing assumptions regarding the relationships between the two systems.

Such responses have seldom been studied carefully, but in a context of international cooperation, they take on new roles and importance. They become part of the relationship between legal systems, and failure to view and understand them as such misses an important dimension of that relationship. 